\title{
ACCEPTANCE OF MUSIC STIMULATION THERAPY FOR AUDITORY HALLUCINATION PATIENTS
}

\author{
(Tingkat Penerimaan Terapi Stimulasi Suara pada Pasien Halusinasi Dengar)
}

\author{
Arum Pratiwi, Agus Sudaryanto \\ Prodi Keperawatan Universitas Muhammadiyah Surakarta \\ Jl. A yani Tromol Pos I SOLO, Phone 0271717417 \\ E-mail: arum.pratiwi@ums.ac.id
}

\begin{abstract}
ABSTRAK
Pendahuluan. Meningkatnya angka penyakit jiwa sebagian besar disebabkan oleh kekambuhan. Terapi stimulasi musik pada pasien halusinasi dengar adalah salah satu terapi modalitas keperawatan. Penelitian ini bertujuan untuk menurunkan timgkat kekambuhan pasien terhadap pengalaman halusinasi dengar. Metode. Pasien diminta mendengarkan musik ketika halusinasi muncul, perawat pemberi terapi mendampingi dan mengobservasi selama terapi, setelah terapi selesai pasien diwawancarai menggunakan pertanyaan terbuka bagaimana respons terhadap terapi musik tersebut. Data hasil wawancara kemudian dianalisis menggunakan strategi narrative inquiry. Selain diwawancarai pasien juga diukur jumlah halusinasi yang muncul sebelum terapi. Intervensi diaplikasikan selama satu bulan, dan setelah itu diukur kembali jumlah halusinasi yang muncul. Tingkat keberhasilan dianalisis menggunakan metode quantitative dengan uji Wilcoxon. Hasil. Tema yang bisa dikembangkan yaitu terapi musik menunjukkan respons spesifik dan terapi musik mengacaukan halusinasi. Sedangkan pada analisis kuantitatif secara rata-rata terdapat perbedaan antara sebelum dan sesudah intervensi yaitu adanya perbedaan mean, tetapi secara uji statistik menunjukkan nilai yang tidak signifikan. Diskusi. Terapi stimulasi suara berhasil dan menghilangkan halusinasi yang sedang berlangsung pada pasien dengan diagnose medis skizoprenia undifferentiated dan tidak berhasil pad pasien skizoprenia paranoid.
\end{abstract}

Kata kunci: Terapi modalitas keperawatan, skizopheria, halusinasi dengar

\begin{abstract}
Introduction. The majority of increasing rates of mental illness cases cause by recurrence. Music stimulation therapy on patients with hallucinations is one of the modalities of therapy in nursing care. The purpose of this study was to reduce the recurrence rate of patients experienced with hearing voices. Methods. Patients were asked to listen to music when hallucinations appeared. The nurse was accompanying and observing during therapy. After completion of therapy, patients were interviewed using an open ended question how the response toward the music therapy. Interview data were analyzed using narrative strategies of inquiry. In addition the patients were also measured a number of hallucinations that appeared before therapy. The intervention was applied for one month, and then the patients are repeated its measures by the appearance of hallucinations. The Wilcoxon test was utilized to compare differences between before and after intervention. Result. The themes finding that can be developed were the music therapy shows specific responses and the music therapy disrupts hallucinations. While the quantitative analysis, there were the differences mean between before and after the intervention, but the statistical test showed insignificant value. Discussion. Stimulation therapy of hearing voice panned out and eliminated ongoing hallucinations in patients with a medical diagnosis of undifferentiated schizophrenia, but the response of paranoid schizophrenia patients were unsuccessful.
\end{abstract}

Keywords: Nursing modalities therapy, schizophrenia, auditory hallucinations

\section{INTRODUCTION}

Patients were admitted to the hospital got nonstandard nursing intervention on how to control the hallucinations. Based on observations can be concluded that there is still misperceptions nurse in a mental hospital about the implementation of nursing in an auditory hallucination patient. Furthermore, it is due to the lack of a simple guideline for auditory hallucinatory therapy that should be used by nurses from the mental hospital to perform the intervention. There are several reasons why it needs a new and simple procedure as evaluation to bring about and focuses on the patient's recovery.

First, the current procedure is a complex nursing care that can only be understood by a professional nurse, so the misperception by nonprofessional nurses when applying the nursing actions can be very dangerous for patients. 
Case studies of profession students reported that there was increasing severity in patients with auditory hallucinations after got therapy how to control hallucinations. Yuniartika et al (2010) describes that the evaluation of patient after was given the intervention of the ears close method to control hallucinations by non professional nurses found that they could not control the sounds, consequently, the voices grew louder as perceived by the patient.

Second, many types of guidelines or strategies on how to control the auditory hallucinations, is still evaluating the patient's ability rather than the results of the patient's recovery. Bate (2013) conducted research in the inpatient unit at a psychiatric hospital in Jakarta, it can be concluded that applying of the strategy of how to control hallucinations focus on evaluate the severity of a patients, and after was given intervention, the results of the study were to evaluate of cognitive patients' ability and psychomotor ability about how to control auditory hallucinations. Because the guidelines are not focused on the patient's progress, but only articulate the success of the nurse. Handayani (2013) concluded that the patient is able to control hallucinations after was given perception of stimulation while the patients' ability to control of hallucinations and the outcome was not evaluated. Further, this research suggested developing strategies related to nursing performance; this shows that less effective guidelines used by nurses.

Other studies have also been focused on the success of a patient who is able to control hallucinations (Aji, 2012; Qodir, Surtiningrum and Nurulita, 2013) rather than evaluating the effect of the ability of the patient such as how recovery rate. It is therefore important to conduct research to evaluate the patient's recovery.

\section{METHODS}

Respondents in this study were patients with schizophrenia. The number of respondents involved in this study there were 10 patients. The average of suffering from schizophrenia was 10 to 25 years and having auditory hallucinations. During the inpatient care in a psychiatric hospital they got antipsychotic drugs. At the beginning of the study managed to recruit 15 patients, but only 10 patients were able to follow up until this study ended. Respondents in this study consisted of male and female. This study used two types of data collection. First, data was obtained by using the interview technique using open-ended question. Second, the data taken with the questionnaire with closed questions that contains of demographic data list and patients' recurrence before and after one month intervention.

In the intervention phase, patients were asked to listen to classical music. Music was played during hallucinations take place or when the patient feels heard the sound. Then, the researchers asked the patient to tell when it will hear a sound. During ongoing therapy researchers observe the patient's reaction to hallucinations. Music therapy is applied for one month with the implementation of one to two times each week. During the intervention, the researchers observe and record the patient's reaction.

The data have been collected from interviews with respondents was the written into the narrative. Next, the data in the form of the narrative is ready to look for the meaning of the data (Transcript review). After read and reread and found the meaning, later, was carried out data reduction to choose words that are important (Story preparation). Then the final stage of data analysis was inquiry Story creation. The researcher begins compiling research results sequentially into a story about a patient experiences auditory hallucinations with stimulation therapy respond.

Data analyze used quantitative approach. Data were analyzed using the Wilcoxon signed rank test to compare the number of hallucinations that appear before and after nursing interventions with distraction therapy.

\section{RESULTS}

The total numbers of 10 participants with schizophrenia were consisted of men of 7 people and female 3 respondents. There were 
$70 \%$ participants have background education of lower than senior high school. Before being diagnosed schizophrenia they worked as selfemployed there were $70 \%$ participants. The mean age of participants was 35 years old. Duration of suffering from schizophrenia was 10 to 25 years.

\section{Patient Acceptance Response of Sound Therapy Stimuli}

Six of ten participants is involved in the interview process. We used pseudonyms in the writing participant's experiences.

\section{Chicha's story}

Chicha is a 45 -year-old woman, a medical diagnosis of paranoid schizophrenia. Average hallucinations appeared 8 times per week. The response to stimulation therapy as follows: Chicha recalled that when the hallucinations start to come, she feels excited, then she tried to insert the ear plug music that given by a nurse. Chicha said that she wanted to try out the sound in accordance with the advice nurse. The nurse evaluated the patient's feelings when she heard the taped music in the ears in ongoing hallucination, Chicha replied that his voice is heard becomes mixed up, "I heard the two of them, so both of them are not clear". Chicha said to feel comfortable with the treatment given nurses. However, he is more comfortable hearing hallucinations.

\section{Rano's story}

Rano is a 32-year-old, male, medical diagnosis of paranoid schizophrenia, on average 13 times per week hearing hallucinations. It was hollow, feels uncomfortable and then the hallucinations start coming in. The patient said that he feels more uncomfortable when listening to music. Music is a disturbing conversation with his hallucinations. Patients are encouraged nurses to try continuing listening to music, but by making the patient wants to upset when the music replaced the hallucinations. Patients are encouraged nurses to try continuing listening to music, but by making the patient wants to upset when the music replaced the hallucinations. $\mathrm{He}$ is more comfortable speaking with the voice. Patients feel more comfortable because it has a supportive friend talked his feelings.

\section{Belina's story}

Bellina was a 32 year old, female, medical diagnosis of paranoid schizophrenia, on average, 11 times per week hearing hallucinations. The hallucinations came to Belina every day. Hallucinations usually came when she was alone. The response to music therapy, the patient said that when given music therapy, music can replace the sounds coming. Belina feeling better after listen the ordinary music therapy. Hallucinations can be interfered with music; however, hallucination is still comes when Belina felt anxious or want to be angry.

\section{Gino's story}

Gino was a 35-year-old; He had medical diagnosis undifferentiated schizophrenia or unclassified schizophrenia, He was male. He heard hallucinations more than 20 times per week. Music stimulation therapy eliminates hallucinations; patients felt more comfortable hearing music therapy then the result in the anxiety decrease, but when he was alone or thinking about his bitter experience, the hallucinations were suddenly come up. When the patient was given music therapy, the hallucination was lost again, and so and so on. The patient is more comfortable after music therapy. But he never lost his hallucinations.

\section{Yoan's story}

Yoan was a 32 year old, male. He got a medical diagnosis of unclassified schizophrenia (undifferentiated schizophrenia). He very often heard voices, hallucinations appear more than 15 times per week. When the patient was given sound stimulation of music therapy in a state of hallucination come, the music can disrupt and eliminate the hallucinations. Hallucinations disappear and the patient turned into the sound of music heard. Anxiety is reduced when he was listening to music. After completion of therapy the patient felt anxiety diminished. 


\section{Dewa's story}

Dewa was a 28 year old, male, medical diagnosis of paranoid schizophrenia. Hallucinations appear 7 to 10 times per week. The patient hears the sound which is very annoying. Sound appears from time to time, especially when he's anxious. The patient is anxious condition all the time. When the hallucinations appeared and the nurse asked to hear classical music, his response was mediocre. He felt uncomfortable with the music that is heard when the hallucinations come, but it can mess up the sound. Although music can disrupt his auditory hallucinations but the sound was still coming regularly every day.

\section{Differences Appearing of Hallucination Before and After Music Therapy}

Before was given nursing intervention of music therapy, interviews were conducted on a number of respondents to the occurrence of hallucinations for one month. Interviews were conducted in the patients with asking how many times per day to hear the sound. Data is noted in a table form. The table form consisted of the patient's name and lists the number of hallucinations that experienced by patients per day in a month. Then the data was re-collected after were given music therapy to determine differences in the appearance of hallucinations between before and after intervention. The information were obtained in the form of numerical data then analyzed with quantitative analysis.

The incidence of hallucinations in 10 respondents described that there had average 31.6 times the patients hearing hallucinations per week before the intervention, while the average of hearing hallucinations was 29.9 times per week after intervention. So there is a difference 17 times and the average is only 1.7 times per week. The results of different test analysis showed that there were differences in mean before and after intervention that was decreased, but in the statistical analysis, there was insignificant differences in $\mathrm{P}$ value of 0.0548 .

\section{DISCUSSION}

Patient's response towards music stimulation therapy showed a variety of different reactions to patients or respondents. Some patients had good responds to distraction, music therapy can managed and mess hallucinations, and on the other hand, the patient was disturbed by music therapy. They were interrupted when an ongoing hallucination then was given music therapy.

For example, the response from Rano and Belina, although patients sometimes understand that sound was heard not real, the patient explained that the sound seems real. They felt comfortable and had friends who support them, so there was lack of successful when was conducted distraction therapy. Videbeck (2010) explains that the schizophrenia patients who experienced phase three hallucination, they hear voice clearly and understand the content of hallucinations. They feel comfortable with the hallucination. Zarghami, Moonesi and Khademiloo (2012) argued that hallucinations not only can be controlled with psychotropic medications but may also in other ways such as distraction, but Stuart and Laraia (2005) explains that nursing therapy in patients with auditory hallucinations is important to evaluate its success.

In addition to differences in individual responses, the tendency towards response differences is also determined by the type of schizophrenia. In the type of paranoid schizophrenia that had experienced hallucinations, the music therapy is not effective to eliminate or disrupt hallucinations, and the patient became angry and annoyed by the distraction therapy. Paranoid schizophrenic patients have a tendency in a state of anxiety. Videbeck (2009) explains that the patient is in a state of anxiety has a tendency to focus on the issues being considered, so it is difficult to receive stimuli from outside, external stimuli received by the patient as it is disturbing. Townsend (2011) explains that the type of paranoid schizophrenia patients have a high level of anxiety, and if there is a discrepancy in the hope patients may result in anger like run amuck. 
In contrast, music therapys tend to be successful in patients with a medical diagnosis of unclassified schizophrenia (undifferentiated schizophrenia-type). Patients with this medical diagnosis have symptoms of hallucinations and delusions. In the case, the music therapy can sensitize patients and can eliminate the voice that the patient heard. The voices were stimulated and distracted using the sound of music. Townsend (2011) explains that unclassified schizophrenia has symptoms of hallucinations but does not have a high emotional or aggressiveness. Therefore, it is more easily stimulated using music therapy. Additionally, Videbeck (2009) argues that patients who do not have high anxiety are easily to be stimulated by something diversions like listening to music.

The difference the number of hallucinations between before and after the intervention result in the difference in the average, but there are not significant in in statistical tests. From the table observations, which is calculated for one month before and after the intervention, changes of the number of patient's hallucinations is very fluctuating. The emergence of hallucinations in patients affected by many factors including the number of visits the patient's family in a month, interactions with other patients, interactions with nurses, where all these activities are the contact between the patient and the patient's environment orients reality. According to Townsend (2011) one treatment program to reduce hallucinations in patients with schizophrenia is through reality orientation program. Based on the response of patients, to evaluate the success of the music therapy intervention or treatment takes longer time. Several studies conducted the music therapy takes six to twelve months to show a success.

\section{CONCLUSION}

The response of patients with schizophrenia who experienced hallucinations towards music therapy is different. Music therapy is successful in controlling hallucinations in a certain diagnosed.

\section{RECOMMENDATION}

Music therapy should be tested on a group of patients with the same medical diagnosis with a control group. The study should take approximately one year to assess the success of the research program and the alkaline control group in patients with the same characteristics.

\section{REFERENCES}

Aji, P.W. (2012). Asuhan keperawatan pada pasien halusinasi dengar di rumah sakit jiwa Surakarta. Diterima dari: http://digilib.stikeskusumahusada.ac.id/ files/disk1/5/01-gdl-wahyupunto-232-1wahyupu-4.pdf.

Bate, A.R. (2013). Pengaruh penerapan strategi pelaksanaan halusinasi terhadap kemampuan pasien menontrol halusinasi dengar di rumah sakit jiwa Soeharto Heerdjan Jakarta. Diterima dari: http://digilib.esaunggul.ac.id/ public/UEU-Undergraduate-211abstrak.pdf

Handayani, D. (2013). Gambaran tingkat kemandirian pasien dalam mengontrol halusinasi setelah mengikuti TAK stimulasi persepsi. Diterima dari:http:// pustaka.unpad.ac.id/archives/124540/.

Qodir, M.A., Surtiningrum, A dan Nurulita, U. (2013). Pengaruh terapi aktivitas kelompok orientasi realita terhadap kemampuan mengontrol halusinasi di RSJD Amino Gondohutomo Semarang. Diterima dari: http://180.250.144.147/ ejournal/index.php/ilmukeperawatan/ article/view/158/182

Schulzt and Videbeck (2009). Psychiatrics Mental Health Nursing, Philadelphia, Davis Company

Stuart, G.W., \& Laraia, M.T. (2005). Principles and Practice of Psychiatric Nursing, Missouri: Mosby.

Towsend, M.C. (2008). Psychiatrics Mental Health Nursing, Philadelphia, Davis Company.

Towsend, M.C. (2011). Nursing Diagnosis in Psychiatrics Nursing, Philadelphia, Davis Company. 
Jurnal INJEC Vol. 2 No. 1 April 2015: 97-102

Videbeck, S.L. (2010). Psychiatric-mental

Zarghami, M., Moonesi, F.S., \& Khademloo, health nursing. Lippincott Williams \& Wilkins.

Yuniartika, W., Sahuri, T., Faozi, E., Wahyudi, A., Anggoro, D., Yulian, V. (2010) Laporan praktik mahasiswa profesi di rumah sakit jiwa Surakarta. Tidak dipublikasikan. M. (2012). Control of persistent auditory hallucinations (three case reports). European review for medical and pharmacological sciences, 16, 64-65. 